\section{A slot in the dock predicted for the chemical industry}

Natasha Loder, London

The chemical industry could be facing a future filled with liability claims sparked by increased knowledge of the human genome, according to a British environmental group.

A report by Friends of the Earth, Crisis in Chemicals, warns that knowledge derived from the Human Genome Project on how chemicals affect individuals could open the legal floodgates. The group also calls for new legislation on the toxicity of chemicals.

New genomics data will mean that the chemical industry will be able to look at the human effects of a new product before it is made available. But it also means that companies failing to do so might face legal liabilities for negligence.

Industry, governments and the financial sector need to recognize the full implications of the biomedical revolution, says Michael Warhurst, one of the report's authors. "Companies that fail to clean up their act will face a heavy bill," he says. "So will insurers and investors."

The UK government has welcomed the report. "It highlights the possible implications of emerging research into the genetic susceptibility of individuals to chemicals, and rightly points out that this research will eventually bring a better understanding of the mechanisms of chemical toxicity," says a spokesperson.

Friends of the Earth predicts that, without action now, there will be a crisis in the regulation and use of chemicals. The UK government is due to hold a 'stakeholder forum' on the regulation of chemical use in the next few months, where this will be discussed and which Friends of the Earth says it will attend.

But Warhurst says that Europe is where the real action on chemical regulation is taking place, and the European Commission is currently reviewing the regulation of industrial chemicals. A UK government spokesperson says: “The report makes some interesting recommendations for the future of European chemical legislation which we will be studying carefully."

The Chemical Industries Association, a lobbying umbrella group for the UK chemical industry, has responded to the report by saying that a programme of "product stewardship" currently ensures that "nobody is exposed to danger from our products". It adds that the chemical industry "is extremely highly regulated". http://www.foe.co.uk

http://www.cia.org.uk

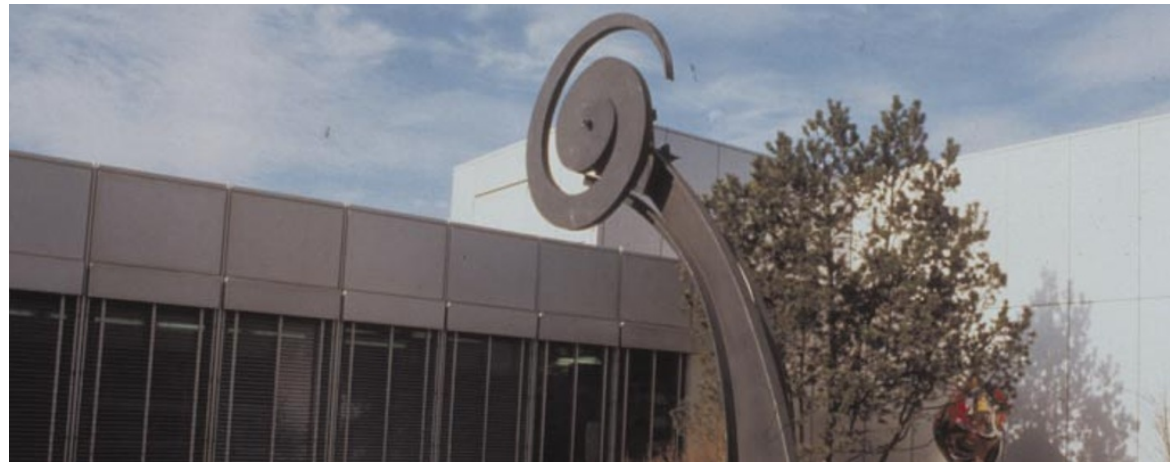

End of an era: funded as an experiment for 30 years by Roche, but left free to direct its own research, the Basel Institute for Immunology is set to close down.

\title{
Roche brings down curtain on Swiss immunology lab
}

Alison Abbott, Munich

The Swiss-based pharmaceutical company Roche announced this week that it is to close its prestigious Basel Institute for Immunology (BII), which has been home to three Nobel prizewinners. The institute will be transformed into a medical genomics centre under the interim directorship of Klaus Lindpaintner, head of Roche's genetics activities in Europe.

The move brings to an end the 30-year experiment of a research institute being supported in its entirety by a pharmaceutical company, and given complete academic freedom to pursue any line of research in immunology.

The BII's 160 employees are in shock. Although Roche had indicated three years ago its waning interest in supporting the institute, discussions had never been sufficiently intense to suggest that such a radical move was on the near horizon, says Fritz Melchers, BII's director for the past 20 years.

Roche has enjoyed significant reflected glory from the BII, which cost SFr40 million (US\$24 million) per year to run. But it has not enjoyed any profit, and has not picked up a single lead from the institute's research. "The model Roche invented was never taken up by other companies," points out Jonathan Knowles, head of Roche's global research organization.

Knowles says that "it was appropriate to support the BII 30 years ago, when the worlds of academia and the pharmaceutical industry were strictly separate". But times have changed. "Academics and industry are now happy to work together synergistically," he says. The company will work much more closely with the new Roche Center for Medical Genomics than it did with the BII, where he says that a lack of dialogue had become an issue of concern to the company.

Knowles says that the model of operation will be similar to that of the Glaxo Institute for
Molecular Biology in Geneva, at which he was director until joining Roche two years ago.

The Center for Medical Genomics will focus its activities on common diseases with complex genetic bases, such as cardiovascular disease, cancer, and psychiatric and neurodegenerative disorders, using human material rather than model organisms.

Roche has pledged to help all the staff find new jobs either within or outside the new institute. Nearly all staff are on five-year contracts, and these will be honoured.

Melchers is distressed by Roche's decision with which he, along with the international scientific advisory board, disagrees. Having done what he feels he could to help ensure the continuation of the institute, he appears to accept defeat philosophically. "Ultimately a company must be able to make its own decisions about its directions," he says. "I may not agree with this decision, but I respect it."

$\mathrm{He}$ is also disappointed about the failure of Roche's attempts, encouraged by the advisory board, to transfer the institute to a local university. The universities could not afford the running costs.

Nobel laureate Robert Huber, a director at the Max Planck Institute for Biochemistry in Munich, and a member of the BII's scientific advisory board, says that "the BII has been a world-leading institute and its closure is very, very sad". He adds: "But in retrospect I wish there had perhaps been a closer dialogue between the institute and the company - then it might not have come to this.'

Manfred Eigen, of the Max Planck Institute for Biophysical Chemistry in Göttingen, is another of the advisory board's Nobel laureates, and a member of its board of directors. He says that the board chose to dissolve itself when it learnt of Roche's decision last week, rather than endorse a decision that it believed to be wrong. "But of course Roche fully financed the BII, and thus has the right to do what it wants." 